\title{
PENGARUH KEBISINGAN TERHADAP KOMUNIKASI PEKERJA PABRIK PT. $X$, KECAMATAN MANIS MATA, KABUPATEN KETAPANG
}

\author{
Vilda Rahmawati' ${ }^{1)}$, Yulisa Fitrianingsih ${ }^{1)}$, Suci Pramadita ${ }^{1)}$ \\ 1)Program Studi Teknik Lingkungan Jurusan Teknik SIpil Fakultas Teknik Universitas Tanjungpura, Pontianak \\ Email: vildarahmawati.st@gmail.com
}

\begin{abstract}
ABSTRAK
PT. X merupakan salah satu perusahaan perkebunan kelapa sawit yang berlokasi di Kecamatan Manis Mata, Kabupaten Ketapang. Proses produksi minyak kelapa sawit menggunakan mesin berkapasitas tinggi dan pengoperasian cukup panjang. Dimana kegiatan tersebut berpotensi menimbulkan kebisingan yang dapat mengganggu kesehatan pekerja salah satunya gangguan komunikasi. Sementara itu, Peraturan Menteri Tenaga Kerja dan Transmigrasi No. 13 tahun 2011 telah menetapkan bahwa nilai ambang batas kebisingan sebesar $85 \mathrm{~dB}$. Tujuan penelitian ini yaitu mengidentifikasi sumber mesin produksi yang berpotensi menghasilkan kebisingan melebihi nilai ambang batas dan mengidentifikasi pengaruh tingkat kebisingan terhadap komunikasi pekerja yang terpapar kebisingan melebihi nilai ambang batas. Berdasarkan hasil pengukuran, sumber stasiun produksi yang berpotensi menghasilkan tingkat kebisingan melebihi nilai ambang batas tertinggi tanpa dipengaruhi aktivitas stasiun produksi lainnya terjadi pada stasiun power house dengan nilai sebesar 96,2 dB dan tingkat kebisingan terendah terjadi pada stasiun loading ramp dengan nilai sebesar 66,8 dB. Sedangkan tingkat kebisingan melebihi nilai ambang batas tertinggi dengan dipengaruhi aktivitas stasiun produksi lainnya terjadi pada stasiun kernel dengan nilai sebesar $97 \mathrm{~dB}$ dan tingkat kebisingan terendah terdapat pada stasiun loading ramp dengan nilai sebesar 69,3 dB. Hasil statistik menggunakan SPSS versi 18.0 dengan uji regresi sederhana didapatkan dari hasil kuesioner menunjukkan bahwa pengaruh tingkat kebisingan terhadap komunikasi pekerja yang terpapar kebisingan melebihi nilai ambang batas sebesar $21 \%$ yang termasuk dalam tingkatan "rendah". Dimana nilai tersebut menyatakan bahwa kebisingan memiliki pengaruh yang signifikan terhadap komunikasi pekerja, yang dapat dilihat pada hasil tes audiometri. Berdasarkan hasil uji audiometri dari 32 responden, 59\% diantaranya mengalami penurunan daya dengar dengan kategori tingkat pengaruh "gradasi berat".
\end{abstract}

Kata Kunci : Tingkat Kebisingan, Sumber Bunyi, Komunikasi Pekerja

\begin{abstract}
$X, L t d$. is an oil palm plantation company located in Manis Mata District, Ketapang Regency. The production process of palm oil uses high capacity machine and long operation time. Where such activities potentially cause noise that can interfere with the health of workers, one of which is a communication disruption. Meanwhile, Minister of Manpower and Transmigration Decree No. 13 Year 2011 has determined that the noise threshold value is $85 \mathrm{~dB}$. The purpose of this research is to identify the source of production machine that has the potential to generate noise exceeding the threshold value and to identify the effect of noise level on the communication of the workers exposed to noise exceeds the threshold value. Based on the measurement, the source of the production station that has the potential to produce the noise level exceeding the highest the threshold value without affected the activity of other production stations is at the power house station with a value of $96.2 \mathrm{~dB}$ and the lowest noise level occurs at the loading ramp station with a value of $66.8 \mathrm{~dB}$. While the noise level exceeding the highest the threshold value by affected the activity of other production stations is at the kernel station with a value of $97 d B$ and the lowest noise level occurs at the loading ramp station with a value of $69.3 \mathrm{~dB}$.Statistical results using SPSS version 18.0 with simple regression test obtained from the questionnaire result showed that the noise level effect on the communication of exposed workers exceeds the threshold value of 21\% which is included in the "low" category. Where the value states that noise has a significant effect on the communication of workers, which can be seen on the results of audiometric test. Based on the results of audiometric test of 32 respondents, 59\% of them experienced a decrease in hearing power with the category of influence of "heavy gradation".
\end{abstract}

Keywords: Noise Level, Sound Source, Communication Workers 


\section{PENDAHULUAN}

Kemajuan dan perkembangan industri setelah lahirnya revolusi industri hingga saat ini menghasilkan suatu teknologi yang semakin modern. Harapan dari lahirnya revolusi tersebut guna mempermudah pekerjaan manusia sehingga industri dapat menghasilkan produk secara maksimal dan efisien. Namun tanpa disadari penggunaan teknologi yang telah dipilih industri juga tidak dapat menjamin kesehatan dan keselamatan pekerja, salah satunya adalah gangguan komunikasi akibat penggunaan mesin-mesin secara otomatis.

Menurut Anizar (2012), menyatakan bahwa penggunaan mesin-mesin otomatis dan berkapasitas tinggi dapat menimbulkan suara yang cukup besar hingga menyebabkan kebisingan, yang dapat memberikan dampak terhadap gangguan komunikasi, konsentrasi, kepuasan kerja bahkan sampai pada cacat pada pekerja. Tahun 2015 WHO menyatakan bahwa 466 juta orang di dunia (432 juta dewasa dan 34 juta anak-anak) yang memiliki gangguan pendengaran yang diakibatkan oleh beberapa faktor termasuk akibat pajanan kebisingan yang berlebihan.

Kegiatan industri merupakan salah satu tempat penyumbang kebisingan terbesar. PT. X merupakan perusahaan perkebunan kelapa sawit berdiri pada tanggal 18 September tahun 1998 yang berlokasi di Kecamatan Manis Mata, Kabupaten Ketapang. Dimana kegiatan yang dilakukan pekerja PT. X dalam mengolah kelapa sawit menjadi minyak tentunya melewati beberapa proses yang berhubungan dengan mesin berkapasitas tinggi dengan pengoperasian yang cukup panjang sehingga berpotensi menimbulkan kebisingan. Berdasarkan kegiatan produksi yang dilakukan PT. $X$ secara berulang-ulang dalam rentang waktu yang lama, dikhawatirkan jika intensitas kebisingan yang diterima para pekerja setiap harinya melebihi nilai ambang batas (NAB) dapat menimbulkan gangguan komunikasi dalam bekerja hingga mengakibatkan hilangnya daya dengar yang tetap dan menurunnya produktivitas pekerja untuk waktu kerja secara terus menerus.

Berdasarkan permasalahan diatas maka perlu dilakukan penelitian mengenai "Pengaruh Kebisingan terhadap Komunikasi Pekerja Pabrik PT. X, Kecamatan Manis Mata, Kabupaten Ketapang" guna mengetahui dampak serta tindakan preventif bagi pekerja yang terkena paparan kebisingan melebihi Nilai Ambang Batas (NAB).

\section{METODOLOGI PENELITIAN}

Penelitian akan dilaksanakan di PT. X yang berlokasi di Kecamatan Manis Mata, Kabupaten Ketapang. Pengambilan sampel dilakukan selama dua hari yaitu hari Jum'at dan Sabtu pada tanggal 20-21 Oktober 2017. Pengukuran pada hari jum'at dilakukan untuk mengetahui tingkat kebisingan yang dihasilkan stasiun produksi dengan dipengaruhi aktivitas stasiun produksi lainnya. Pengukuran tingkat kebisingan dilakukan pada empat waktu yang disesuaikan dengan Kepmen LH 48 tahun 1996 bahwa waktu pengukuran pada siang hari paling sedikit dilakukan sebanyak empat waktu, yakni pagi hari pada pukul $08.00 \mathrm{WIB}$, siang hari pada pukul $10.00 \mathrm{WIB}$, sore hari pada pukul 15.00 WIB dan malam hari pada pukul 20.00 WIB. Sedangkan pengukuran pada hari sabtu bertujuan mengetahui tingkat kebisingan yang dihasilkan stasiun produksi tanpa dipengaruhi aktivitas stasiun produksi lainnya. Pengukuran hari sabtu hanya dilakukan satu waktu saja, yakni pada pukul 10.00 WIB. Pengukuran tingkat kebisingan dilakukan pada 8 stasiun produksi dengan menggunakan alat sound level meter sedangkan untuk mengetahui pengaruh kebisingan terhadap komunikasi pekereja menggunakan kuesioner setelah itu diolah menggunakan statistic SPSS (Statistic Product and Service Solutions) versi 18.0 kemudian untuk mengetahui tingkat pendengaran pekerja dilihat dari komunikasi dengan dilakukan tes audiometri dengan jumlah sampel sebanyak 32 responden. Dimana 32 responden tersebut sudah dianggap mewakili jumlah titik sampel pengukuran, yakni 8 stasiun produksi. 


\section{HASIL DAN PEMBAHASAN}

A. Pengukuran Potensial Kebisingan Stasiun Produksi

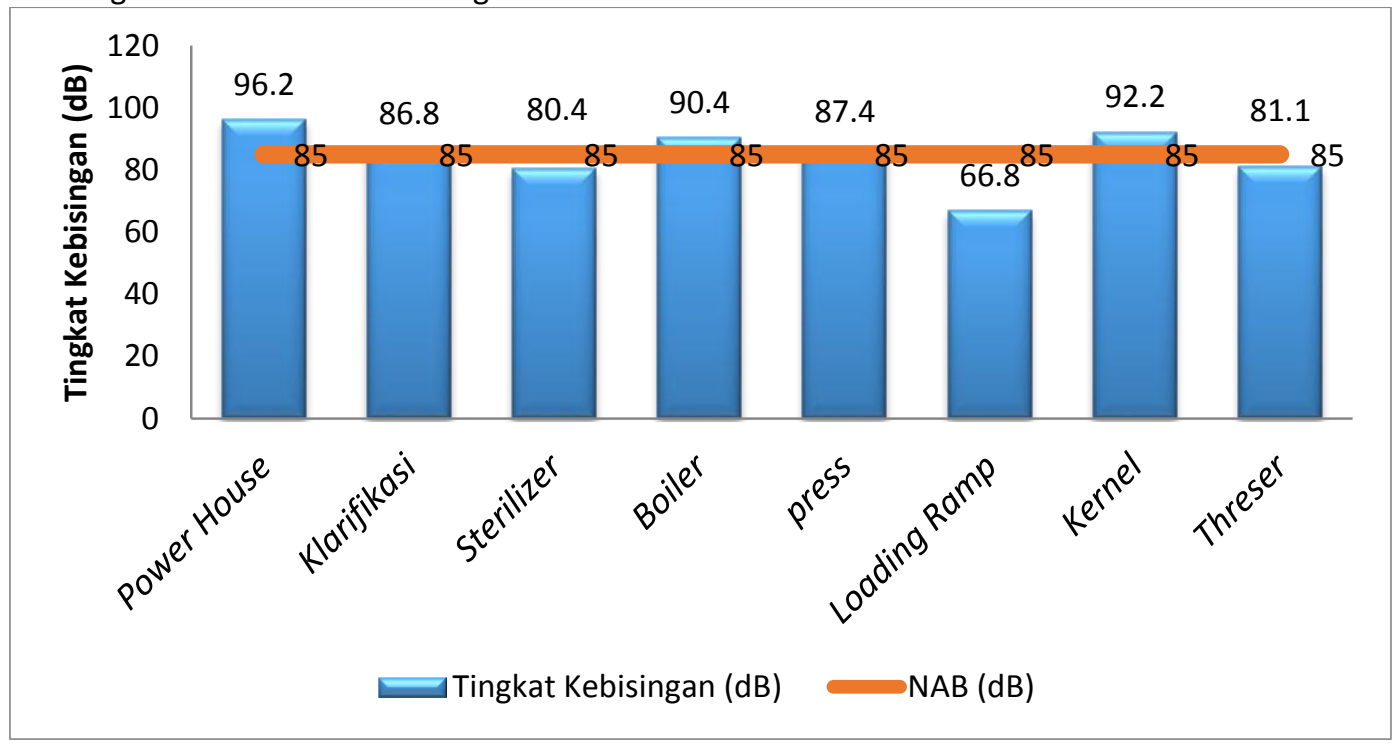

Gambar 1 Pengukuran Potensial Kebisingan Stasiun Produksi

Pengukuran pada Gambar 1 dilakukan pada hari sabtu tanggal 21 Oktober 2018 pukul 10.00 WIB. Dimana nilai ambang batas pada penelitian ini mengacu pada Peraturan Menteri Tenaga Kerja dan Transmigrasi No. 13 tahun 2011 menyatakan bahwa nilai ambang batas tingkat kebisingan sebesar 85 dB. Berdasarkan Gambar 1 dapat diketahui hasil pengukuran tingkat kebisingan yang melewati nilai ambang batas terjadi pada stasiun power house, klarifikasi, boiler, press dan kernel dengan tingkat kebisingan tertinggi terdapat pada stasiun power house yakni sebesar 96,2 dB. Hal ini didukung dengan pernyataan Saputra, dkk (2015), bahwa penggunaan mesin-mesin produksi pada saat beroperasi menghasilkan intensitas kebisingan yang melebihi nilai ambang batas. Dilihat dari hasil pengukuran berdasarkan peraturan IATA (International Air Transport Association) tingkat kebisingan pada PT. $X$ termasuk pada zona $D$ dengan batas maksimum kebisingan sebesar $115 \mathrm{~dB}$, dimana pekerja wajib menggunakan alat pelindung diri yaitu ear plug demi menjaga kesehatan dan keselamatan pekerja.

\section{B. Pengukuran Tingkat Kebisingan Saat Operasional}

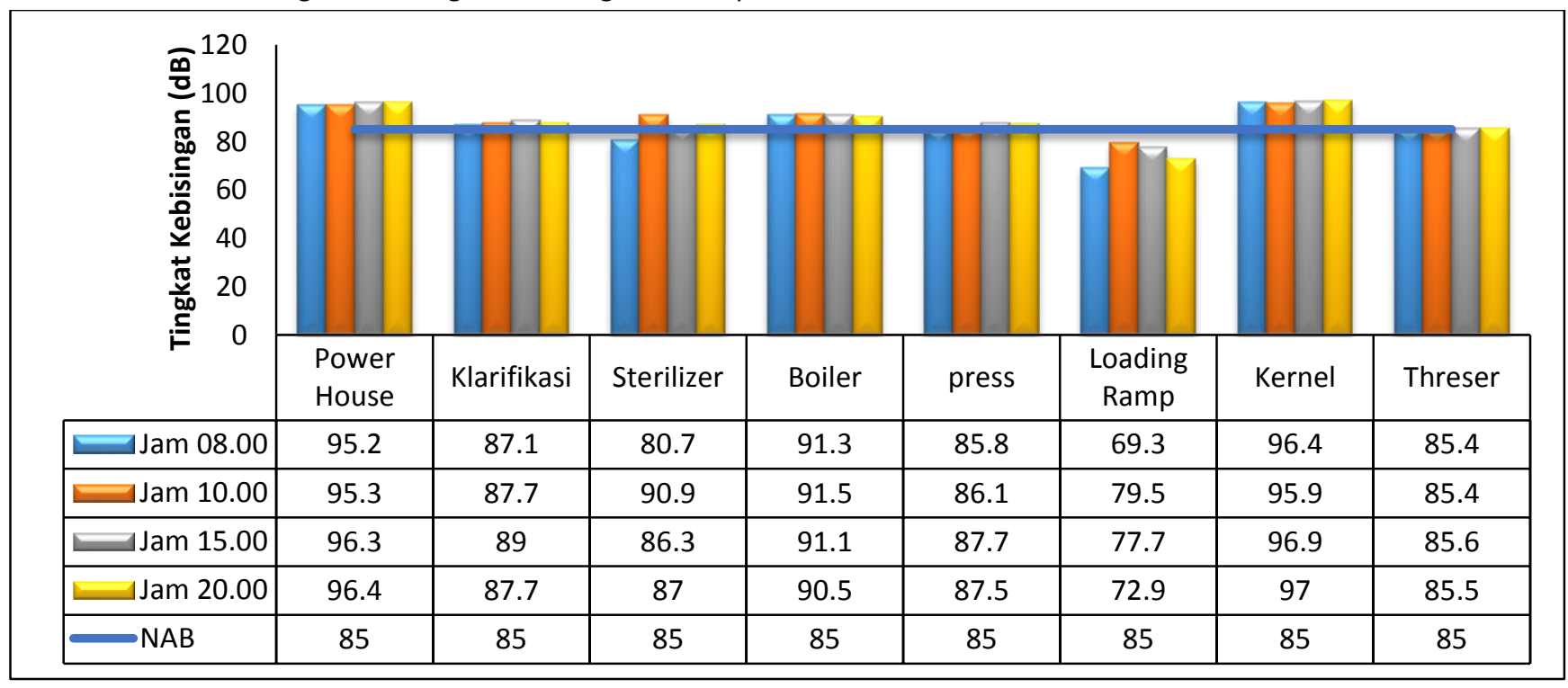

Gambar 2 Pengukuran Tingkat Kebisingan Saat Operasional 
Pengukuran tingkat kebisingan pada saat operasional dilakukan pada hari jum'at tanggal 20 Oktober 2018 dengan waktu pengukuran mengacu pada Kepmen LH 48 tahun 1996 yang menyatakan bahwa waktu pengukuran pada siang hari paling sedikit dilakukan sebanyak 4 waktu yang mewakili yakni 08.00, 10.00, 15.00 dan 20.00 WIB. Berdasarkan Gambar 2 dapat diketahui hampir semua stasiun melebihi nilai ambang batas dengan tingkat kebisingan tertinggi pada stasiun kernel sebesar 97 dB pada pukul 20.00 WIB. Hal ini dikarenakan kegiatan masing-masing stasiun beroperasi secara terus menerus dan jarak pada masing-masing stasiun tidak jauh sehingga peneliti berpendapat bahwa tingkat kebisingan yang dihasilkan telah terakumulasi dengan stasiun lainnya. Hal lain yang menghasilkan kebisingan, yakni pengoperasian mesin stasiun produksi dengan kapasitas tinggi yang menghasilkan suatu getaran, gesekan atau tubrukan antara mesin satu dengan yang lainnya yang membuat tingkat kebisingan bertambah. Kemudian suhu juga berpengaruh terhadap peningkatan kebisingan pada saat pengukuran suhu area pabrik diatas batas normal yakni, panas berdasarkan Keputusan Menteri Kesehatan Republik Indonesia No. 1405/Menkes/IX/2002 Tentang Standar Suhu Lingkungan Kerja untuk Perindustrian yaitu $18^{\circ} \mathrm{C}$ $30^{\circ} \mathrm{C}$. Mesin-mesin yang bekerja secara terus menerus dengan kapasitas tinggi dapat membuat suhu meningkat sehingga membuat mesin menjadi panas dan cepat rusak, membuat tingkat kebisingan bertambah serta membuat pekerja menjadi cepat lelah karena lingkungan kerja yang kurang menudukung.

Berdasarkan pendapat Suma'mur (1996), menyatakan bahwa suhu udara yang panas dan lembab, makin tinggi kecepatan aliran udara malah akan makin membebani tenaga kerja. Pada tempat kerja dengan suhu udara yang panas maka akan menyebabkan proses pemerasan keringat, beberapa hal buruk berkaitan dengan kondisi demikian dapat dialami oleh tenaga kerja, salah satunya kelelahan kerja. Sedangkan menurut Tagor (2005), yang menyatakan bahwa di tempat kerja disadari maupun tidak cukup banyak fakta yang menunjukkan bahwa perusahaan beserta aktivitasnya ikut menciptakan dan menambah keparahan tingkat kebisingan di ternpat kerja, misalnya mengoperasikan mesin-mesin produksi ribut yang sudah cukup tua, terlalu sering mengoperasikan mesin-mesin berkapasitas cukup tinggi dalam periode operasi cukup panjang, sistem perawatan dan perbaikan mesin-mesin produksi alat kadarnya (hanya pada saat rusak). Berdasarkan peraturan IATA (International Air Transport Association) tingkat kebisingan pada PT. $X$ termasuk pada zona $D$ dengan batas maksimum kebisingan sebesar $115 \mathrm{~dB}$, dimana pekerja wajib menggunakan alat pelindung diri yaitu ear plug demi menjaga kesehatan dan keselamatan pekerja.

\section{Hasil Pengolahan Data Kuesioner}

\section{- Usia Pekerja}

Usia pekerja pada PT. X, yakni mulai dari usia 20 tahun hingga 54 tahun. Batas usia karyawan bekerja yang telah ditetapkan oleh pihak pabrik, yakni berumur 55 tahun. Dibawah ini merupakan diagram hasil berdasarkan usia pekerja yang bekerja pada stasiun produksi.

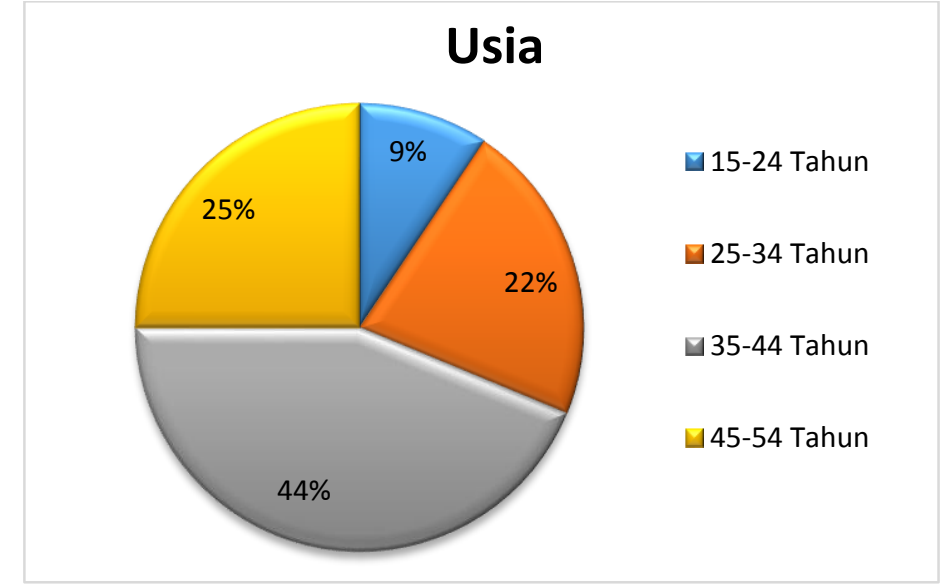

Gambar 3 Hasil Berdasarkan Usia Pekerja

Berdasarkan Gambar 3 dapat diketahui hasil berdasarkan usia pekerja pada PT. X dari 32 responden bahwa sebagian besar usia pekerja adalah 35 - 44 tahun dengan persentase 
tertinggi yakni $44 \%$, berusia 45 - 54 tahun dengan persentase $25 \%$, berusia 25 - 34 tahun dengan persentase $22 \%$ dan usia 15 - 24 tahun dengan persentase $9 \%$. Adapun batas usia kerja produktif menurut Undang-Undang Tenaga Kerja No. 13 Tahun 2003 adalah berumur 15 tahun - 64 tahun. Berdasarkan hal tersebut dapat disimpulkan bahwa usia pekerja pada PT. X masih termasuk dalam usia produktif atau masih memenuhi standar usia kerja untuk di Indonesia yang mana usia pekerja masih dalam rentang 20 tahun - 54 tahun.

\section{- Lama Masa Kerja}

Lama masa pekerja bekerja di PT. X yakni 3 bulan hingga 20 tahun. Dibawah ini merupakan diagram hasil berdasarkan lama masa kerja pekerja bekerja pada stasiun produksi.

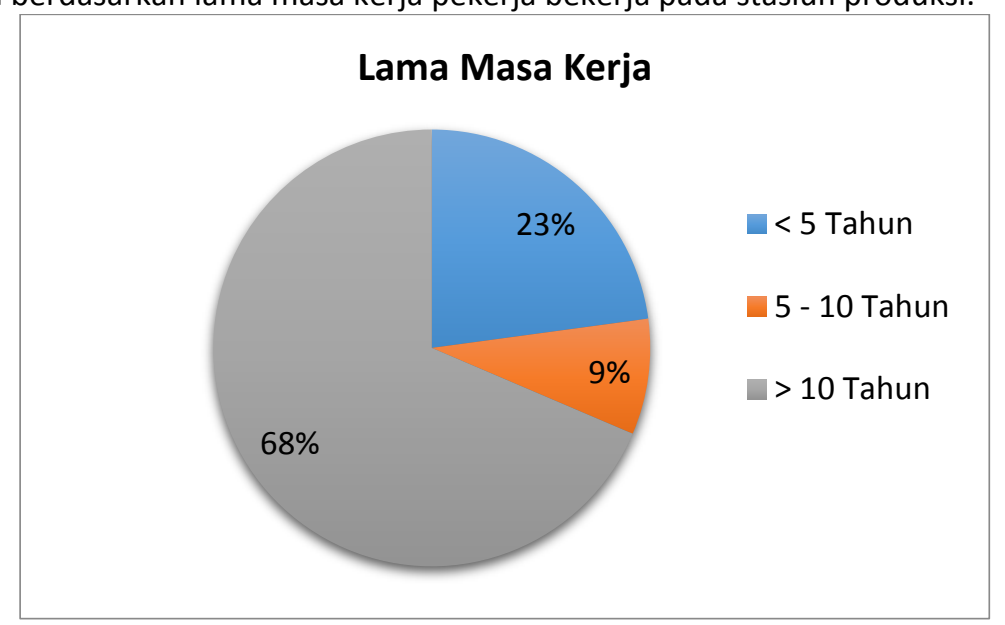

Gambar 4 Hasil Berdasarkan Lama Masa Kerja

Berdasarkan Gambar 4 dapat diketahui hasil lamanya usia pekerja di PT. X dari 32 responden yakni dengan lamanya bekerja adalah selama lebih dari 10 tahun yakni 11 tahun hingga 20 tahun dengan persentase terbesar 68\%, sedangkan untuk masa kerja kurang dari lima tahun yakni satu tahun hingga 4 tahun dengan persentase $23 \%$ dan untuk masa kerja dalam rentang lima hingga 10 tahun mendapati persentase 9\%. Menurut Suma'mur (2009), berpendapat bahwa lama usia kerja diatas lima tahun, yakni dimana tenaga kerja memiliki kepuasan dalam bekerja yang terus meningkat sampai lama kerja diusia ke lima tahun dan kemudian pada usia kerja ke 8 mulai terjadi penurunan, tetapi kemudian setelah tahun kedelapan maka kepuasan kerja secara perlahan-lahan akan meningkat kembali. Oleh karena itu alasan banyak yang bekerja di PT. X lebih dari 10 tahun dikarenakan kepuasan kerja responden secara perlahan-lahan telah meningkat kembali.

\section{- Penggunaan Alat Pelindung Diri}

Penggunaan alat pelindung diri pada PT. $X$ beradasarkan stasiun yang dijaga oleh pekerja yang disesuai dengan jenis pekerjaannya. Dibawah ini merupakan diagram hasil berdasarkan penggunaan alat pelindung diri yang digunakan pekerja selama di area stasiun produksi. 


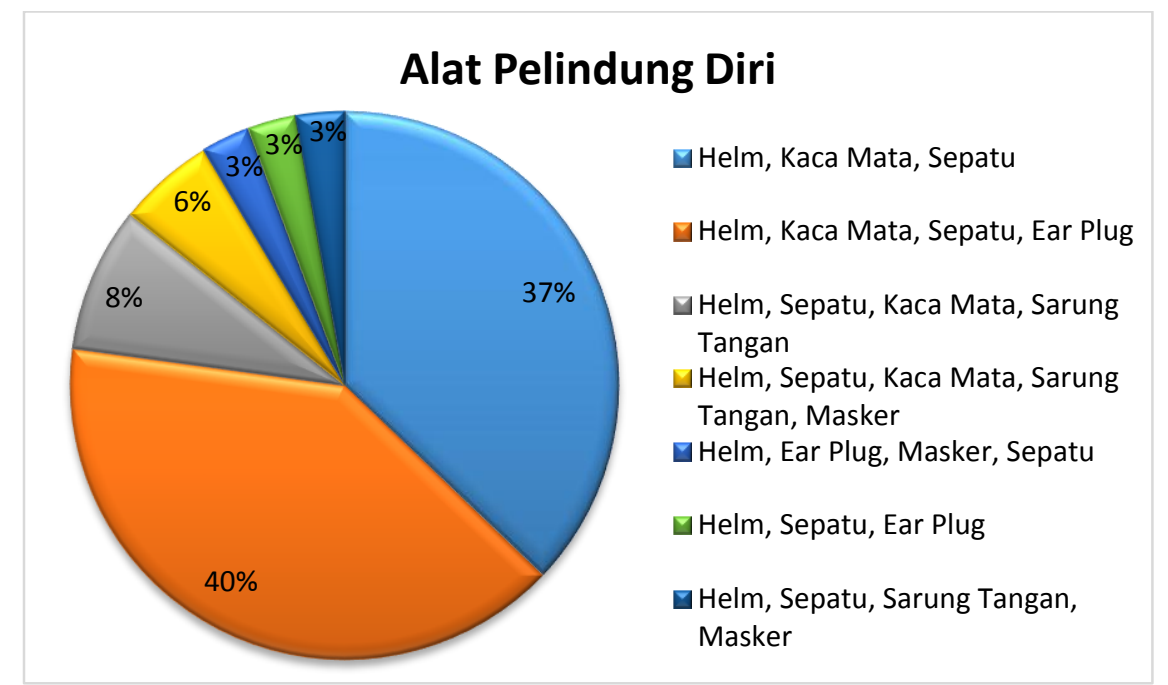

Gambar 5 Hasil Berdasarkan Alat Pelindung Diri

Berdasarkan Gambar 5 dapat diketahui bahwa penggunaan alat pelindung diri yang digunakan pekerja pada PT. X dari 32 responden dengan persentase terbesar $40 \%$ yakni penggunaan alat pelindung diri lengkap sesuai dengan Peraturan Menteri Tenaga Kerja dan Transmigrasi No. 08 tahun 2010 yang telah digunakan pekerja seperti helm, kaca mata, sepatu dan ear plug. Dimana kesehatan dan keselamatan kerja telah difasilitasi oleh PT. $\mathbf{X}$ dengan penggunaan alat pelindung diri dengan harapan untuk menghindari kecelakaan akibat kerja pada saat berkerja. Namun pada kenyataannya pekerja masih menganggap remeh dengan penggunaan alat pelindung diri tersebut tanpa memikirkan efek samping untuk kedepannya. Menurut Melamed dkk (1996), menyatakan bahwa alasan utama karyawan tidak mau menggunakan alat pelindung diri, khususnya alat pelindung telinga adalah karena ketidaknyamanan dan gangguan komunikasi yang dirasakan oleh karyawan itu sendiri.

D. Analisis Uji Linier Regresi Sederhana

Analisis hubungan tingkat kebisingan terhadap komunikasi pekerja menggunakan alat kuesioner yang disebar kepada 32 responden yang bekerja di stasiun produksi yang telah diukur. Analisis yang digunakan pada penelitian ini, yakni analisis linier regresi sederhana dengan tujuan mengtahui pengaruh variabel bebas (independent) terhadap variabel terikat (dependent). sedangkan metode yang digunakan dalam penelitian, yakni metode Enter. Metode ini yang paling sederhana dalam mendapatkan persamaan regresi. Semua variabel dalam metode ini dijadikan satu grup dalam persamaan. Berikut merupakan tabel analisis regresi sederhana:

Tabel 1 Model summary

\begin{tabular}{|c|c|c|c|c|}
\hline Model & $\mathrm{R}$ & R Square & $\begin{array}{c}\text { Adjusted } \mathrm{R} \\
\text { Square }\end{array}$ & $\begin{array}{c}\text { Std. Error of the } \\
\text { Estimate }\end{array}$ \\
\hline 1 & $0,458^{\mathrm{a}}$ & 0,210 & 0,184 & 1,78419 \\
\hline
\end{tabular}

a. Predictors : (Constant), Tingkat Kebisingan

Berdasarkan Tabel 1 dapat diketahui nilai $\mathrm{R}, \mathrm{R}^{2}$, Adjusted $\mathrm{R}^{2}$ dan Std. Error. Dimana hasil nilai korelasi (R) yakni sebesar 0,458 yang berarti $45,8 \%$. Berdasarkan tabel nilai koefisien dan kekuatan hubungan menurut Misbahuddin dan Hassan (2013), hasil 45,8\% termasuk dalam tingkatan "cukup berarti atau sedang". Sedangkan untuk besarnya persentase dalam menyumbangkan pengaruh variabel bebas terhadap variabel terikat yang dinyatakan sebagai koefisien determinasi $\left(R^{2}\right)$. Hasil koefisien determinasi $\left(R^{2}\right)$ sebesar 0,210 yang berarti bahwa $21 \%$ sumbangan pengaruh variabel bebas (tingkat kebisingan) terhadap variabel terikat (komunikasi), dimana nilai tersebut termasuk dalam tingkatan "rendah". Menurut Bangun (2009), menyatakan bahwa walaupun 
tingkat kebisingan yang diterima oleh seseorang tinggi dan berbahaya, namun terdapat beberapa orang yang merasa tidak terganggu dengan tingkat kebisingan yang dirasakan dikarenakan mereka sudah terbiasa terpapar dengan tingkat kebisingan dengan intensitas tinggi dan sebaliknya.

E. Hasil Tes Audiometri

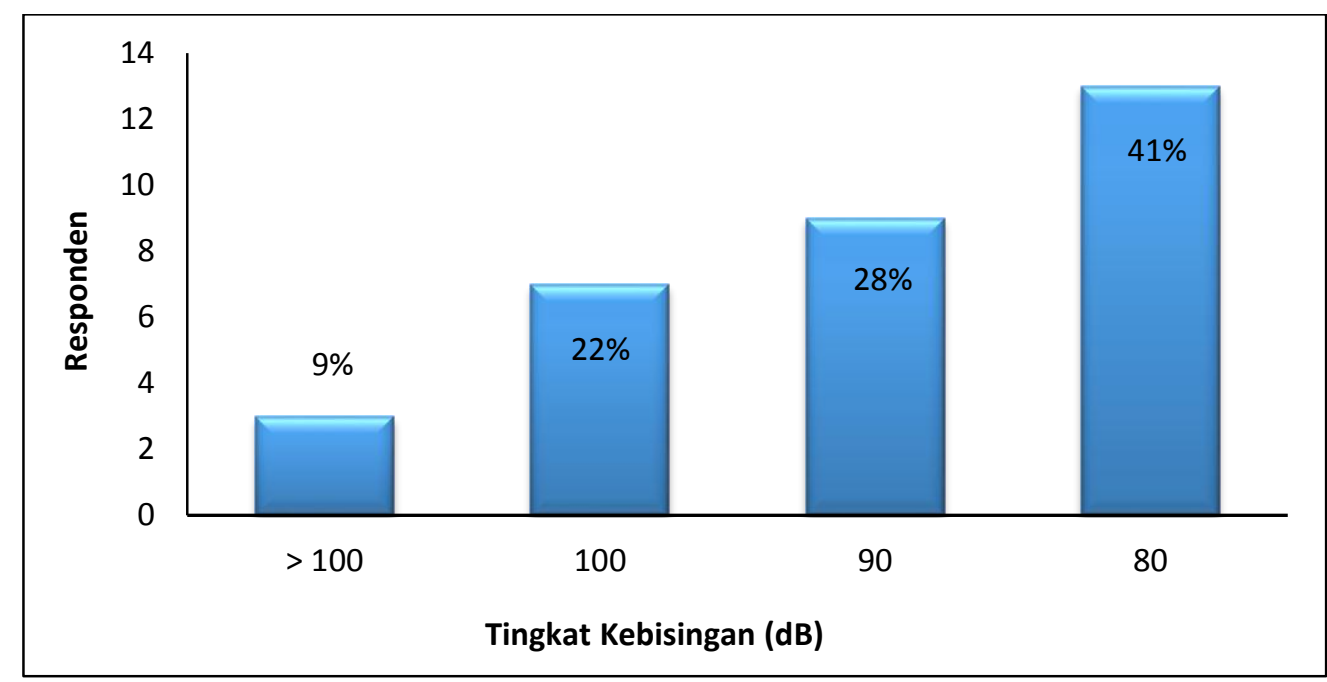

Gambar 6 Persentase Responden Merasa Bising (dB)

Berdasarkan Gambar 6 dapat diketahui bahwa dari 32 reponden terdapat 13 responden merasa bising pada intensitas $80 \mathrm{~dB}$ dengan persentase terbesar yakni $41 \%, 9$ responden merasa bising pada intensitas $90 \mathrm{~dB}$ dengan persentase $28 \%, 7$ responden merasa bising pada intensitas $100 \mathrm{~dB}$ dengan persentase $22 \%$ dan 3 responden merasa bising pada intensitas $>100 \mathrm{~dB}$ dengan persentase terendah yakni, 9\%. Hal ini terjadi dikarenakan kebanyakan dari responden tidak menggunakan alat pelindung diri yang difasilitasi oleh pabrik sebagaimana mestinya dan menganggap alat pelindung diri tidak menjadi kewajiban yang mutlak pada saat di dalam pabrik guna untuk meminimalisir resiko kecelakaan pada saat bekerja yang tentunya dapat merugikan pihak pabrik maupun responden itu sendiri. Menurut Moreta, dkk (2001), menyatakan walaupun penggunaan alat pelindung diri telah diketahui secara teoritis dapat mengurangi dan menekan munculnya potensi risiko, namun beberapa alasan masih sangat sulit untuk diterapkan. Hal ini didukung dengan pendapat Melamed, dkk (1996), menyatakan bahwa faktor utama alasan karyawan tidak menggunakan alat pelindung telinga adalah karena ketidaknyamanan dan gangguan komunikasi yang dirasakan oleh karyawan.

Berdasarkan tabel batas tingkat kebisingan untuk pendengaran manusia menurut Buchari (2007) dapat diketahui 59\% responden termasuk dalam kategori tingkat pengaruh "gradasi berat (tuli berat)", dimana dalam penelitian ini jarak yang digunakan adalah 1 meter (kurang dari 1,5 meter). Berdasarkan pendapat yang dikemukakan oleh beberapa para ahli diatas dapat disimpulkan bahwa komunikasi 59\% atau 19 responden mengalami penurunan daya dengar dengan katagori "gradasi berat", dengan suara bising yang dapat diterima dengan jelas oleh beberapa responden mulai dari intensitas kebisingan $60 \mathrm{~dB}$ sampai $70 \mathrm{~dB}$ dan baru merasakan bising di atas $70 \mathrm{~dB}$.

\section{F. Upaya Mereduksi Kebisingan}

Berdasarkan hasil analisis yang telah dilakukan, dapat diketahui tingkat kebisingan pada PT. $X$ Wilayah Desa Manis Mata, Kecamatan Manis Mata, Kabupaten Ketapang hampir semua stasiun produksi yang telah diukur melewati nilai ambang batas, yakni lebih dari $85 \mathrm{~dB}$. Hal tersebut tentunya dalam jangka panjang dapat berdampak serius terhadap kesehatan dan keselamatan pekerja hingga membuat produktivitas bekerja menjadi menurun. Guna meminimalisir keadaan tersebut diperlukan upaya untuk mereduksi tingkat kebisingan yang disebabkan oleh kegiatan 
stasiun produksi dalam mengolah kelapa sawit menjadi minyak kelapa sawit. Adapun upaya mereduksi kebisingan dapat dilakukan dengan beberapa cara, yakni adalah sebagai berikut:

\section{- Pengendalian pada Sumber}

Menurut Imansyah dan Ahmad (2006), menyatakan bahwa pengendalian pada sumber bising dengan melakukan upaya agar tingkat bising yang dihasilkan oleh sumber dapat dikurangi atau dihilangkan sama sekali. Adapun pengendalian pada sumber peneliti rekomendasikan pada PT. X, yakni:

1. Melakukan perawatan dan pengecekan terhadap tiap stasiun produksi secara berkala oleh pengurus yang berwenang meliputi pengecekan harian, mingguan dan bulanan agar stasiun produksi selalu terjaga, tahan lama dan dapat beroperasi secara optimal.

2. Menjaga suhu pada area pabrik agar tetap stabil sehingga tidak membuat mesin menjadi panas karena pemuaian yang dapat membuat mesin menjadi macet sehinga mesin tidak berkerja secara maksimal dan dapat mengurangi umur mesin. Berdasarkan Keputusan Menteri Kesehatan Republik Indonesia Nomor 1405/Menkes/IX/2002 tentang Standar Suhu Lingkungan Kerja untuk Perindustrian yaitu $18^{\circ} \mathrm{C}-30^{\circ} \mathrm{C}$.

3. Menutup mesin atau mengisolasi mesin sehingga terpisah dengan pekerja. Teknik ini menurut Tarwaka, dkk (2004) dapat dilakukan dengan cara mendesain mesin dengan menggunakan remote control. Sehingga suara bising yang dihasilkan dapat tereduksi, jadi dengan begitu pemaparan tingkat kebisingan yang diterima pekerja dalam batas yang masih bisa ditoleransi pendengaran atau dibawah nilai ambang batas (NAB).

\section{- Pengendalian pada Medium}

Menurut Imansyah dan Ahmad (2006), menyatakan bahwa upaya pengendalian kebisingan pada medium dapat dilakukan melalui struktur bangunan (structure borne noise). Adapun cara pengendalian pada medium peneliti rekomendasikan pada PT. X, yakni dengan memperhatikan konstruksi bangunan, salah satunya adalah dinding. Dimana dinding yang digunakan PT. X sebagai sekat secara umum sudah sesuai dengan pendapat Ratrian (2009), hanya saja dinding pada PT. $X$ tidak dilapisi dengan dempul namun pada vent gas sudah didempul dengan lapisan tebal dari material penyerap suara. Adapun kriteria bangunan dinding sebagai berikut:

- Mempunyai massa yang cukup dan merata diseluruh bidang dindingnya.

- Dibangun secara horizontal dan vertikal sebagai penghalang yang solid.

- $\quad$ Tertutup secara efektif dan merata pada lapisan permukaannya.

- Dinding bersih dan terang, permukaan yang selalu terkena percikan air terbuat dari bahan yang kedap air.

- Penutup harus merupakan dempul yang tidak mengelupas dan tidak mengeras dan harus menghindari sambungan adukan semen yang encer dan kosong karena dapat menghasilkan kobocoran pada bising.

\section{- Pengendalian pada Penerima}

Menurut Imansyah dan Ahmad (2006), menyatakan bahwa pengendalian pada penerima yaitu melakukan upaya perlindungan pada pendengar (manusia) yang terkena paparan bising (noise exposure) dengan intensitas tinggi dan waktu yang cukup lama. Adapun pengendalian pada penerima peneliti rekomendasikan pada PT. X, yakni:

- Mengurangi waktu bekerja pada pekerja yang terpapar kebisingan >85 dB yang disesuikan dengan Peraturan Menteri Tenaga Kerja dan Transmigrasi No. 13 tahun 2011.

- Memindahkan pekerja yang terpapar kebisingan >85 dB pada stasiun produksi dengan tingkat kebisingannya masih dapat ditoleransi oleh pendengaran, yakni dengan tingkat kebisingan maksimum sebesar $85 \mathrm{~dB}$.

- $\quad$ Pihak perusahaan bersikap tegas bagi pekerja yang tidak mematuhi peraturan yang telah diberlakukan demi menjaga kesehatan dan keselamatan kerja.

- Memberikan apresiasi kepada pekerja yang taat dan disiplin terhadap peraturan, sehingga pekerja lain saling termotivasi untuk memperbaiki kinerjanya terhadap perusahaan.

- Memasuki area pabrik diberlakukan metode check list sehingga bagi pekerja yang tidak lengkap menggunakan alat pelindung diri sesuai dengan Peraturan Menteri Tenaga Kerja 
dan Transmigrasi Republik Indonesia NO PER.08/MEN/VII/2010 tentang Alat Pelindung Diri tidak bisa masuk, hal ini dilakukan demi menjaga keselamatan pekerja dan nama baik perusahaan.

\section{KESIMPULAN} berikut:

Berdasarkan penelitian yang telah dilakukan, maka dapat disimpulkan beberapa hal sebagai

1. Sumber stasiun produksi yang berpotensi menghasilkan kebisingan melebihi nilai ambang batas tertinggi tanpa dipengaruhi aktivitas stasiun produksi lainnya terdapat pada stasiun power house dengan nilai sebesar 96,2 dB dan tingkat kebisingan terendah terdapat pada stasiun loading ramp dengan nilai sebesar 66,8 dB. Menurut Peraturan Menteri Tenaga Kerja dan Transmigrasi No. 13 tahun 2011 bahwa baku mutu terpapar kebisingan sebesar $85 \mathrm{~dB}$. Sedangkan tingkat kebisingan melebihi nilai ambang batas tertinggi dengan dipengaruhi aktivitas stasiun produksi lainnya terjadi pada stasiun kernel dengan nilai sebesar $97 \mathrm{~dB}$ dan tingkat kebisingan terendah terdapat pada stasiun loading ramp dengan nilai sebesar 69,3 dB.

2. Pengaruh tingkat kebisingan terhadap komunikasi pekerja pada PT. X Kecamatan Manis Mata, Kabupaten Ketapang berdasarkan hasil analisis kuesioner menggunakan statistik dengan bantuan aplikasi SPSS (Statistical Product and Service Solutions) versi 18.0 dengan metode skala likert dan uji regresi sederhana didapatkan dari hasil kuesioner pengaruh tingkat kebisingan terhadap komunikasi pekerja yang terpapar kebisingan melebihi nilai ambang batas sebesar $21 \%$ yang termasuk dalam tingkatan "rendah". Dimana nilai tersebut menyatakan bahwa kebisingan memiliki pengaruh yang signifikan terhadap komunikasi pekerja, yang dapat dilihat pada hasil tes audiometri. Berdasarakan hasil tes audiometri dari 32 responden terdapat $59 \%$ mengalami penurunan daya dengar dan termasuk dalam kategori tingkat pengaruh "gradasi berat (tuli berat)".

\section{UCAPAN TERIMA KASIH}

Terima kasih kepada Ibu Yulisa Fitrianingsih dan Ibu Suci Pramadita selaku dosen pembimbing skripsi, Ibu Dian Rahayu Jati dan Ibu Laili Fitria selaku dosen penguji skripsi, Pihak PT. X, Kecamatan Manis Mata, Kabupaten Ketapang, serta semua pihak yang terlibat dan membantu penulis selama proses pengerjaan penelitian yang tidak dapat diucapkan satu persatu.

\section{DAFTAR PUSTAKA}

Anizar, 2012. Teknik Keselamatan dan Kesehatan Kerja di Industri. Yogyakarta: Graha IImu. World Health Organization (WHO). 2015. Deafness and Hearing Loss. Fact sheet Number 300. Revisi Maret 2015. Website:http://www.who.int/mediacentre/factsheets/fs300/en/

Bangun, L. P. 2009. Kebisingan Lalu Lintas dan Hubungannya Dengan Tingkat Ketergangguan Masyarakat (Studi Kasus: Jalan Bojongsoang, Kabupaten Bandung). Bandung: Institut Teknologi Bandung.

Buchari. 2007. Kebisingan Industri dan Hearing Conservation Program. USU: Universitas Sumatra Utara.

Hasan, Misbahuddin Iqbal. 2013. Analisis Data Penelitian Dengan Statistik Edisi ke-2. Jakarta: Aksara.

Imansyah B. S., Achmad R. D. 2006. Bising Ancam Pendengaran. Bandung: Pikiran-Rakyat.

Keputusan Menteri Kesehatan Republik Indonesia No. 1405/MENKES/SK/XI/2002. Persyaratan Kesehatan Lingkungan Kerja Perkantoran dan Industri. Indonesia.

Keputusan Menteri Negara Lingkungan Hidup No. 48, 1996. Baku Tingkat Kebisingan Menteri Lingkungan Hidup. Indonesia.

Melamed S, Rabinowitz S, Feiner M, Weisberg E, Ribak J. 1996. Usefulness of the protection motivation theory in explaining hearing protection device use among male industrial workers. Health Psychology.

Morata TC., Fiorini AC, Fischer FM, Krieg EF, Gozzoli L, Colacioppo S. 2001. Factors affecting the use of hearing protectors in a population of printing workers. Noise and Health. 
Peraturan Menteri Tenaga kerja Dan Transmigrasi Republik Indonesia No. 08 tahun 2010. Alat Pelindung Diri. Jakarta: Departeman Kesehatan RI.

Peraturan Menteri Tenaga Kerja dan Transmigrasi. No. 13 tahun 2011. Nilai Ambang Batas Faktor Fisika dan Kimia di Tempat Kerja. Jakarta: Departeman Kesehatan RI.

Ratrian, Nugroho. C., 2009. Pemetaan dan Upaya Reduksi Intensitas Kebisingan pada Bangunan Rumah Sakit (Studi Kasus RSUD Budhi Asih Jakarta). Jakarta: Teknik Asitektur Universitas Indonesia.

Sihar, Tagor. 2005. Kebisingan di Tempat Kerja. Yogyakarta: ANDI.

Suma'mur, P. K., 1996. Higiene Perusahaan dan Kesehatan Kerja. Jakarta: CV. Haji Masagung.

Suma'mur, P. K., 2009. Higiene Perusahaan dan Kesehatan Kerja (Hiperkes). Jakarta: CV. Sagung Seto.

Tarwaka, Solichul HA, Bakri, Sudiajeng L. 2004. Ergonomi Untuk Keselamatan, Kesehatan Kerja dan Produktivitas. Surakarta: Universitas Balikpapan Press.

Undang - Undang Nomor 13 tahun 2003 tentang Ketenagakerjaan (Lembaran Negara Republik Indonesia Tahun 2003 Nomor 39, Tambahan Lembaran Negara Republik Indonesia Nomor 4279). Jakarta: Departemen Tenaga Kerja RI. 